\title{
Evaluation of Concentrations of Hazardous Components to Support Removal of the Tank 48 Thermowell (U)
}

by

G. K. Georgeton

Westinghouse Savannah River Company

Savannah River Site

Aiken, South Carolina 29808

This paper was prepared in connection with work done under the above contract number with the U. S.

Department of Energy. By acceptance of this paper, the publisher and/or recipient acknowledges the U. S. Government's right to retain a nonexclusive, royalty-free license in and to any copyright covering this paper, along with the right to reproduce and to authorize others to reproduce all or part of the copyrighted paper. 


\section{DISCLAIMER}

This report was prepared as an account of work sponsored by an agency of the United States Government. Neither the United States Government nor any agency thereof, nor any of their employees, makes any warranty, express or implied, or assumes any legal liability or responsibility for the accuracy, completeness, or usefulness of any information, apparatus, product, or process disclosed, or represents that its use would not infringe privately owned rights. Reference herein to any specific commercial product, process, or service by trade name, trademark, manufacturer, or otherwise does not necessarily constitute or imply its endorsement, recommendation, or favoring by the United States Government or any agency thereof. The views and opinions of authors expressed herein do not necessarily state or reflect those of the United States -Government or any agency thereof.

This report has been reproduced directly from the best available copy.

Available to DOE and DOE contractors from the Office of Scientific and Technical Information, P. O. Box 62, Oak Ridge, TN 37831; prices available from (615) $576-8401$.

Available to the public from the National Technical Information Service, U. S. Deparment of Commerce, 5285 Port Royal Rd., Springfield, VA 22161 


\section{DISCLAIMER}

Portions of this document may be illegible in electronic image products. Images are produced from the best available original document. 
HIGH LEVEL WASTE ENGINEERING

TANK FARM STUDIES SECTION

\section{UNCLASSIFIED \\ DOES NOT CONTAN UNCLASSIFED CONTAOLLO}

Date: $\frac{\text { ADe : }}{\text { Reviewing }}$

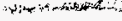

,
WSRC-TR-94-0467

REVISION: 0

KEYWORDS:

High Level Waste

Engineering, Mercury,

Benzene, TCLP,

Tetraphenylborate

RETENTION:

PERMANENT

CLASSIFICATION:

UNCLASSIFIED

$\overbrace{\substack{\text { Authorized Derivative } \\ \text { Classifier }}} q_{10 / 10 / 94}$

EVALUATION OF CONCENTRATIONS OF HAZARDOUS COMPONENTS TO SUPPORT REMOVAL OF THE TANK 48 THERMOWELL (U)

B Y

G. K. GEORGETON

September 28, 1994
Date: $9 / 29 / 24$

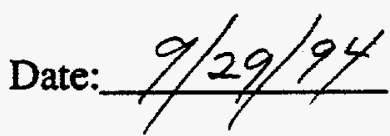

Date: $9 / 29 / 94$

Date: $9 / 29 / 24$

Date: $10 / 5 / 94$ idvickert for

T. M. Monahon, Manager, HLWE 


\section{INTRODUCTION}

In support of start-up activities for the In Tank Precipitation (ITP) process, a thermowell is scheduled to be removed from Tank 48. Disposal of the thermowell in the Solid Waste Disposal Facility (SWDF) requires manifesting the quantities of several radioisotopes and, equally important, declaring that the waste package is nonhazardous. Sampling of the waste in the package (i.e., the thermowell) to determine quantities of hazardous materials or to perform a Toxicity Characteristic Leaching Procedure (TCLP) is not prudent or practical. Extremely high dose rates due to contamination of the thermowell preclude any close contact to obtain smear samples, and obtaining a representative sample of the various parts of the thermowell for a TCLP is not feasible.

Alternatively, the TCLP can be simulated using a limited amount of data supplemented with process knowledge. This information can be further developed into a conservative screening tool to provide guidance on declaring whether the waste package is hazardous or not. This report documents the information and calculations of hazardous component concentrations used to support the possible disposal of the Tank 48 thermowell.

\section{SUMMARY}

Calculations were performed to evaluate if a thermowell to be removed from Tank 48 will be hazardous due to contamination from waste in that tank. Process knowledge and historical analytical data were used to simulate the TCLP determination for the waste package, using conservative scaling factors relating benzene and mercury to ${ }^{137} \mathrm{Cs}$. Benzene (as a result of hydrolysis of precipitate during a TCLP) was determined to exceed the hazardous threshold at a lower ${ }^{137} \mathrm{Cs}$ level than for mercury and as such, is the more restrictive hazardous component. In order to declare that the liquid waste from Tank 48 will not cause the package to be hazardous, the ${ }^{137} \mathrm{Cs}$ contamination of the thermowell must be less than $0.072 \mathrm{Ci}$.

\section{DISCUSSION}

Tank 48 is the main processing vessel for the ITP operations, where sodium tetraphenylborate (NaTPB) will be added to HLW salt solutions to decontaminate the solution by removal of soluble ${ }^{137} \mathrm{Cs}$. Potassium (typically present in the salt solution at about 20 times the ${ }^{137} \mathrm{Cs}$ concentration) and mercury also react with tetraphenylborate (TPB). Potassium and cesium TPB and diphenylmercury are, for practical purposes, insoluble and precipitate from solution. The resulting solids initially float on the liquid surface due to the relatively high density of the salt solution, and eventually settle as the salt solution is diluted during the washing stages of the ITP process.

A full scale demonstration of the ITP process was conducted in 1983 [1] using 427,000 gal of reconstituted salt solution from Tank 24 . Sodium tetraphenylborate was added to precipitate the ${ }^{137} \mathrm{Cs}$ in the solution, and the resulting precipitate has remained in Tank 48. Tank histories reflect that, since the demonstration, only nonradioactive process chemicals, water, and, in October 1990, RBOF waste $(126,000$ gal) have been added to Tank 48 [2].

The hazardous components of concern in Tank 48 are benzene $(\mathrm{Bz})$ and mercury $(\mathrm{Hg})$. Benzene is formed when the TPB precipitate radiolytically and chemically degrades, but benzene has a very small solubility in salt solution. More importantly though, benzene would be generated during the TCLP on waste contaminated with precipitate, due to the hydrolysis caused by the leaching solution (acetic acid). Mercury is present in High Level Waste (HLW) supernate at varying concentrations, and was transferred into the tank in the Tank 24 solution. Mercury reacts with 
TPB to form diphenylmercury, which decomposes to some degree upon contact with acetic acid in the TCLP. (Nitrobenzene has been observed during a TCLP of a filter plugged with nonirradiated simulant to evaluate the future disposal of ITP filters [3]. Nitrobenzene is generated by reaction of nitrite with TPB in acidic conditions. The nitrobenzene limit of $2 \mathrm{mg} / \mathrm{l}$ was exceeded by a small amount, although there was some uncertainty regarding the quality of the result. For the Tank 48 thermowell, the nitrite concentration and the quantity of solids would be considerably lower than in the conditions of the filter TCLP. The nitrobenzene concentration in the leachate would be much less and is, therefore, not considered to be of concern.)

\section{Method Description}

The thermowell in Tank 48 will be contaminated with TPB solids and supernate. Much of the contamination can be removed by spraying with water as the equipment is being drawn out of the tank. Because of the high radiation rate associated with the thermowell, the quantity of waste that remains on the surface (or trapped inside) cannot be determined by conventional measurement techniques. However, the quantity of the slurry can be estimated by taking advantage of the radioactive decay of ${ }^{137} \mathrm{Cs}$ by using the inventory to "trace" other components.

The ${ }^{137} \mathrm{Cs}$ content of the waste package will be obtained by converting field exposure rate readings (the only "sample" information available) to the number of curies of ${ }^{137} \mathrm{Cs}$. Based on process knowledge of the operations associated with Tank 48 , the inventory of components of interest can be estimated. Combined with a knowledge of the chemistry occuring in the tank and in the TCLP, the quantities of hazardous components can be related to the ${ }^{137} \mathrm{Cs}$ concentration in the form of scaling factors. The concentrations of the hazardous components in the leachate from a TCLP are then calculated using the ${ }^{137} \mathrm{Cs}$ content of the waste package and the scaling factors. At the hazardous threshold concentration, the maximum amount of ${ }^{137} \mathrm{Cs}$ that could be included in the package is then calculated.

\section{Component Inventory in Tank 48}

The ${ }^{137} \mathrm{Cs}$ inventory in Tank 48 is almost entirely due to the waste transferred into the tank for the full scale demonstration. Approximately $110,000 \mathrm{Ci}$ of ${ }^{137} \mathrm{Cs}$ were transferred from Tank 24 [1]. Transfer of RBOF waste into Tank 48 introduced less than $190 \mathrm{Ci}$ of ${ }^{137} \mathrm{Cs}$ (based on the highest ${ }^{137} \mathrm{Cs}$ concentration of RBOF waste in the past 3 years [4]). The present inventory, after adjusting for decay, is estimated to be $85,000 \mathrm{Ci}$.

No data were available on the mercury concentration in the salt solution from Tank 24 , so the maximum value of $340 \mathrm{mg} / \mathrm{l}$ for Tank Farm supernate [5] was assumed. The typical $\mathrm{Hg}$ concentration in RBOF waste is $<0.001 \mathrm{mg} / 1$ [6], so the quantity introduced in 1990 was insignificant. Thus, the mercury inventory in Tank 48 was conservatively estimated to be $550 \mathrm{~kg}$.

During the 1983 demonstration, a total of $36,000 \mathrm{lb}$ of NaTPB was added to Tank 48 [1]. Initial testing with cold chemicals consumed approximately $1,300 \mathrm{lb}$ of the NaTPB, and decontamination of the Tank 24 supernate consumed another $8,800 \mathrm{lb}$ (both forming potassium TPB). After the demonstration, $500 \mathrm{lb}$ of insoluble and $1,300 \mathrm{lb}$ of soluble NaTPB remained in Tank 48. The balance was transferred to Tanks 49 and 50 during the dewatering and washing phases of the demonstration. Recently, run-in testing of the ITP facility has also introduced as much as 14,000 $\mathrm{lb}$ of NaTPB [7] into the system. Conservatively assuming that none of the precipitate has decomposed, the inventory of TPB in Tank 48 was estimated to be $24,000 \mathrm{lb}$ ( 93 wt\% of NaTPB is due to the TPB ion). 


\section{Evaluation of TCLP Leachate}

Benzene

Based on the inventory described above, the ratio of TPB to ${ }^{137} \mathrm{Cs}$ is

$$
\mathrm{R}_{\mathrm{TPB} / \mathrm{Cs}}=\left(\frac{24,000 \mathrm{lb}}{85,000 \mathrm{Ci}}\right)=0.28 \frac{\mathrm{lb} \mathrm{TPB}}{\mathrm{Ci}}
$$

As indicated above, this conservatively assumes that all TPB is still present (i.e., has not decomposed) and takes into account decay of ${ }^{137} \mathrm{Cs}$.

Tetraphenylborate compounds, when contacted with the acetic acid specified in the TCLP [8], hydrolyze releasing benzene according to the reaction [9]

$$
\Psi\left(\mathrm{C}_{6} \mathrm{H}_{5}\right)_{4} \mathrm{~B}+\mathrm{CH}_{3} \mathrm{COOH}+2 \mathrm{H}_{2} \mathrm{O}->3 \mathrm{C}_{6} \mathrm{H}_{6}+\mathrm{C}_{6} \mathrm{H}_{5} \mathrm{~B}(\mathrm{OH})_{2}+\Psi \mathrm{OOCCH}_{3}
$$

where $\Psi$ represents either sodium, potassium or cesium. The stoichiometry reflects that 3 moles of benzene are released for every mole of TPB reacted. In mass terms, $234 \mathrm{gm}$ of benzene are produced for every $319 \mathrm{gm}$ of TPB reacted. Combining this ratio with Eqn. (1) and converting units results in a ratio of

$$
R_{\mathrm{Bz} / \mathrm{Cs}}=\left(\frac{234 \mathrm{gm} \mathrm{Bz}}{319 \mathrm{gm} \mathrm{TPB}}\right)\left(\frac{24,000 \mathrm{lb}}{85,000 \mathrm{Ci}}\right)\left(\frac{454 \mathrm{gm}}{\mathrm{lb}}\right)=94 \frac{\mathrm{gm} \mathrm{Bz}}{\mathrm{Ci}}
$$

This conservatively implies that all of the TPB in the TCLP sample will react within the time frame allowed for the TCLP $(18 \pm 2 \mathrm{hrs})$.

The regulatory limit for benzene is $0.5 \mathrm{mg} / \mathrm{l}$ in the leachate, as derived from a $25 \mathrm{gm}$ representative sample contacted with $500 \mathrm{ml}$ of the leaching solution. The amount of benzene in the leachate solution at the TCLP limit is calculated using Eqn. (3).

$$
B_{\text {TCLP }}=\left(0.5 \frac{\mathrm{mg}}{1}\right)(500 \mathrm{ml})\left(\frac{11(\text { iter })}{1000 \mathrm{ml}}\right)=0.25 \mathrm{mg} \mathrm{Bz}
$$

The amount of ${ }^{137} \mathrm{Cs}$ that would be present in the leachate with the $0.25 \mathrm{mg}$ of benzene is

$$
\mathrm{CS}_{\mathrm{TCLP}}=\left(\frac{0.25 \mathrm{mg} \mathrm{Bz}}{94 \frac{\mathrm{gm} \mathrm{Bz}}{\mathrm{Ci}}}\right)\left(\frac{1 \mathrm{gm}}{1000 \mathrm{mg}}\right)=2.7 * 10^{-6} \mathrm{Ci}
$$

The thermowell to be removed from Tank 48 weighs approximately $1470 \mathrm{lb}$ [10]. The mass of any precipitate slurry trapped on or in the thermowell will be small and can be neglected. The maximum amount of ${ }^{137} \mathrm{Cs}$ that can contaminate the thermowell without the benzene limit being exceeded is 


$$
C s_{\max , B z}=\left(\frac{2.7^{*} 10^{-6} \mathrm{Ci}}{25 \mathrm{gm}}\right)(1470 \mathrm{lb})\left(\frac{454 \mathrm{gm}}{\mathrm{lb}}\right)=0.072 \mathrm{Ci}
$$

Therefore, if the ${ }^{137} \mathrm{Cs}$ content (based on radiation exposure measurements) of the waste package is less than $0.072 \mathrm{Ci}$, the benzene concentration in the leachate from a TCLP would be less than the regulatory limit of $0.5 \mathrm{mg} /$, and the waste package will be nonhazardous with respect to benzene.

\section{Mercury}

The mercury inventory in Tank 48 was conservatively estimated to be $550 \mathrm{~kg}$, so the ratio of $\mathrm{Hg}$ to ${ }^{137} \mathrm{Cs}$ is

$$
\mathrm{R}_{\mathrm{Hg} / \mathrm{Cs}}=\left(\frac{550 \mathrm{~kg}}{85,000 \mathrm{Ci}}\right)\left(\frac{1000 \mathrm{gm}}{\mathrm{kg}}\right)=6.5 \frac{\mathrm{gm} \mathrm{Hg}}{\mathrm{Ci}}
$$

Mercury reacts with TPB to produce insoluble diphenylmercury, essentially removing all of the mercury from solution. Diphenylmercury reacts to a limited extent with the acetic acid solution used in the TCLP; however, all of the diphenylmercury that would be in the TCLP sample was conservatively assumed to react completely. At the regulatory limit of $0.2 \mathrm{mg} /$, the amount of mercury that would be in the leachate from a TCLP sample is

$$
\mathrm{Hg}_{\text {TCLP }}=\frac{\left(0.2 \frac{\mathrm{mg}}{\mathrm{l}}\right)(100 \mathrm{gm} * 20)\left(\frac{11 \text { (iter })}{1000 \mathrm{ml}}\right)}{1.0 \frac{\mathrm{gm}}{\mathrm{ml}}}=0.4 \mathrm{mg} \mathrm{Hg}
$$

(Note that a different sample size and execution of the TCLP are used for $\mathrm{Hg}$ than for benzene, due to the latter's volatility. The sample size is $100 \mathrm{gm}$, and the mass of leaching solution is 20 times the mass of the sample.)

The quantity of ${ }^{137} \mathrm{Cs}$ that would be in the TCLP sample was calculated using Eqn. (8).

$$
\mathrm{CS}_{\text {TCLP }}=\left(\frac{0.4 \mathrm{mg} \mathrm{Hg}}{6.5 \frac{\mathrm{gm} \mathrm{Hg}}{\mathrm{Ci}}}\right)\left(\frac{1 \mathrm{gm}}{1000 \mathrm{mg}}\right)=6.2 * 10^{-5} \mathrm{Ci}
$$

Finally, the maximum amount of ${ }^{137} \mathrm{Cs}$ that can contaminate the thermowell without the mercury limit being exceeded is

$$
\mathrm{Cs}_{\mathrm{max}, \mathrm{Hg}}=\left(\frac{6.2^{*} 10^{-5} \mathrm{Ci}}{100 \mathrm{gm}}\right)(1470 \mathrm{lb})\left(\frac{454 \mathrm{gm}}{\mathrm{lb}}\right)=0.41 \mathrm{Ci}
$$

Therefore, if the ${ }^{137} \mathrm{Cs}$ content in the thermowell waste package is less than $0.41 \mathrm{Ci}$, the $\mathrm{Hg}$ concentration in the leachate from a TCLP would be less than the regulatory limit of $0.2 \mathrm{mg} /$, and the package will be nonhazardous with respect to mercury. 
WSRC-TR-94-0467

Revision 0

Page 6 of 7

\section{Field Implementation}

Comparison of the results of the previous section indicate that benzene will cause the thermowell waste package to exceed the hazardous limit at a considerably lower ${ }^{137} \mathrm{Cs}$ loading than for mercury. The TPB solids included with $0.072 \mathrm{Ci}$ of ${ }^{137} \mathrm{Cs}$ will force the benzene to exceed the 0.5 $\mathrm{mg} / \mathrm{h}$ regulatory limit, while mercury at the same ${ }^{137} \mathrm{Cs}$ level is only $18 \%$ of the $0.2 \mathrm{mg} / \mathrm{TCLP}$ threshold. Thus, benzene is the more restrictive component. In order to declare that the liquid waste from Tank 48 will not cause the package to be hazardous, the ${ }^{137} \mathrm{Cs}$ contamination of the thermowell must be less than $0.072 \mathrm{Ci}$.

\section{ACTIONS}

None

\section{REFERENCES}

[1] C. J. Heng, "Salt Decontamination Demonstration - Technical Summary", DPSP-83-17-17, January $5,1984$.

[2] W. S. Cavin and A. T. Crumm, "Waste Transfers and Miscellaneous Addition (U)", WSRC-TR-93-425 Rev. 1, January 21, 1994.

[3] M. F. Morrissey (by D. J. McCabe), "ITP Filter TCLP Study (U)", WSRC-RP-94-917, August 31, 1994.

[4] J. S. Baker, "Radionuclide Transfers from RBOF to Waste Tanks - October 1992", NMP-EHA-920042, November 10, 1992.

[5] G. K. Georgeton, "Characterization of Hazardous Constituents in HLW Supernate and Implications for Solid LLW Generation (U)", WSRC-TR-94-0297, June 22, 1994.

[6] C. J. Coleman, "Analysis of SRP Waste Streams for Waste Tank Certification", DPST-89-281, March 28, 1989.

[7] M. K. Gupta, "Safety Evaluation of the ITP Filter/Stripper Test Runs and Quiet Time Runs Using Simulant Solution (U)", WSRC-TR-92-427, Rev. 3, June 1994.

[8] South Carolina Hazardous Waste Management Regulations, R.61-79.261, Appendix II, Method 1311 Toxicity Characteristic Leaching Procedure (TCLP).

[9] H. E. Shook, "Chemical Characterization of Waste Contaminated with Benzene and Tetraphenylborate from the In-Tank Precipitation Process (U)", Draft, September 1, 1994.

[10] E\&PD Drawing Number M-MF-H-0079 (Old Numbering System W710522), Rev. 17, July $8,1991$. 
cc: M. C. Chandler, 703-H

J. E. Marra, 703-H

V. G. Dickert, 703-H

T. M. Monahon, 703-H

H. E. Shook, 703-H

M. E. Jamison, 703-H

D. Blue, 241-152H

M. J. Hagenbarth, 742-6G

C. G. Lampley, 241-197H

HLWE Files, Code 1.12.1, 703-H 